\title{
Analysis Of Credit Risk Measurement Using CreditRisk+ Method (Study of PT XYZ (Persero) Tbk SME Loans For 2016-2018)
}

\author{
Andrey Carver ${ }^{1}$, Ferdinand D Saragih ${ }^{2}$, Bernardus Yuliarto Nugroho ${ }^{3}$ \\ \{andrey.carver@ hotmail.com ${ }^{1}$, saragih_fds@yahoo.com ${ }^{2}$, nugroho_yuliarto@yahoo.com ${ }^{3}$ \} \\ ${ }^{1,2,3}$ Faculty of Administrative Science, University of Indonesia, Jakarta, Indonesia
}

\begin{abstract}
SME credit is one of the most complex credit segments, this is due to the many factors that affect the credit to be the default. Until now, the method often used to measure credit risk is to use the Standardized Approach method which refers to the provisions of Bass II. Whereas in this method will produce the provision of capital that is not accurate enough. At present Bank XYZ has used the Standardized Approach to measure SME credit risk. The purpose of this study is to measure the credit risk of Bank XYZ SME using the CreditRisk + method.
\end{abstract}

Keywords : Credit risk, SME, CreditRisk+.

\section{Introduction}

The function in the world of banking is to collect and channel funds to the public. In terms of channeling funds to the public, the role of the bank is one of the financial institutions as an intermediary between parties who have funds and those who need funds. Another main function of the bank is to receive public deposits in the form of demand deposits, deposits and savings.

Based on the above explanation, banks in Indonesia, especially commercial banks (public banks), both private and state-owned banks, function as fundraising (funding) from the community in the form of deposits or as a means of storing public money, channeling funds (lending) to the public in the form of loans (credit), and providing services of other banks (sevices) such as payments (transfer of funds), storage of valuables, and services provided in the form of security and supervision of property. With this function, making the bank is one of the important factors and can influence the economy of each country, including in Indonesia.

In bank credit, there are four basic elements, namely maturity, trust, risk, and income. At present, the ratio of bad loans to most commercial banks is very high so that credit risk assessment is not only related to bank profitability, but also plays an important role in maintaining the stability of the entire financial system, which can affect the national economy. XYZ Bank ensures that it has sufficient capital to cover credit risk, market risk and operational risk, both based on regulatory provisions (regulatory capital) and internal needs (economic capital). Bank XYZ refers to Bank Indonesia and OJK regulations (Basel II and Basel III), especially Pillar 1, in calculating capital adequacy for credit risk, market risk and operational risk. For the calculation of capital adequacy, Bank XYZ uses the Basel II Standard Method (Standardized Approach) for credit risk and has included the External Rating component. In addition, gradually Bank XYZ has simulated the Method Based on Internal Ratings (Based Ratings). 
In a survey of 41 major international banks, Brannan, Mengle, Smithson and Zmiewski [1] explained that more than $80 \%$ of banks measured credit risk using the credit portfolio risk measurement method. The most widely used method is CreditMetrics, and CreditRisk + in calculating credit risk. In addition, other methods used but not widely used in calculating credit risk are CreditPortfolio View and Moody's KMV.

From the various methods of measuring credit risk mentioned above, the method used in this study is to use the Credit Risk + method. This method was developed by Credit Suisse First Boston (CSFB) in December 1996. Focus on this method is at the measurement of expected loss and unexpected loss. Thus, in the Credit Risk Plus Method, each individual loan is considered to have a small probability of default, and the probability of default on each loan does not depend on the failure of another loan [2].

Based on the background above, the research questions can be detailed as follows:

a. How much is expected loss and unexpected loss from the Small Medium Enterprise (SME) loan portfolio using the Credit Risk + method?

b. What is the minimum capital that must be reserved by XYZ Bank to cover the Small Medium Enterprise Credit (SME) risk by using the Credit Risk + method?

In accordance with the research problem, the purpose of this study is:

a. Measuring the amount of expected loss and unexpected loss from the Small Medium Enterprise (SME) loan portfolio using the Credit Risk + method

b. Measuring the minimum capital size that must be reserved by Bank XYZ to cover the Small Medium Enterprise Credit (SME) risk by using the Credit Risk + method.

\section{Literature Review}

In its 1996 report the Bank for International Settlement (BIS) [3] defines Credit risk as follows: Credit risk / exposure: the risk that a counterparty will not be obligation for full values, either when due or at any time thereafter. In exchange for value systems, the risk is generally defined as including replacement risk and principal risk.

Saunders [4] states that many dimensions illustrate the differences between credit risk methods. There are around 10 dimension keys from five types of methods. The five credit risk methods are:

a. Option Pricing Methods, for example KMV and Moody's

b. Reduced Form Metodes, represented by KPMG and Kamakura Corporation

c. VaR Method, for example Credit Metrics

d. Time Varying Metodes, for example Credit Portfolio View

e. Mortality Metodes, for example CreditRisk +

Measuring credit risk with a Credit Risk + for a credit portfolio is done by dividing the credit portfolio into several bands. Data components to calculate Credit Risk + are as follows [2]:

a. Exsposures, are outstanding from transactions used by the debtor as a whole. In some transactions it can be used to determine assumptions regarding the level of exposure when a default occurs

b. Default Rates, is the number of events that represent the possibility of defaulting on each debtor. Default Rates can be obtained in several ways, namely

1) Observation of credit spreads from traded financial instruments can be used to obtain probability of default from market valuations.

2) Using a credit rating, along with the mapping from default rates to credit ratings, can be used to determine the best way to find out the probality of default of the debtor 
3) Using continuous scale, can be used instead of a combination of credit rating and default rate.

c. Recovery Rates, is the value of debt that can be paid back by the debtor or that can be billed by the bank.

d. Default Rates Volatilities, are actual default rates that fluctuate around the average value which can be described by the standard deviation (volatility) of the default rates. The standard volatility of default rates when compared to the actual default rates will reflect default fluctuations during the economic cycle.

\section{Methodology}

In this study carried out through literature studies, data collection and quantitative analysis. The nature of research methodology is analytical. Library studies are used to compile the theoretical basis relating to the measurement of credit risk. The data collected is primary data obtained directly from Bank XYZ. In measuring SME credit risk using the Credit Risk + method.

The data analysis method used in this study is quantitative analysis. The process of measuring credit risk using the CreditRisk + method is as follows:

a. Band Preparation

b. Calculating Exposure at Default (EAD)

c. Calculate Recovery Rates

d. Calculate Loss Given Default (LGD) or Severity of Loss

e. Calculate the Default Rates

f. Calculating the Probability of Default and Cummulative Probability of Default

g. Calculating Expected Loss

h. Calculate Unexpected Loss

i. Calculation of Economic Capital

\section{Results \& Discussion}

The first step is making a band. The purpose of making this band is to make the process of measuring credit risk easier, namely by reducing the amount of data by grouping the total debit trays into several groups. The unit of exposure used in this study, namely Rp. 200,000,000; Rp.5,000,000,000; Rp.10,000,000,000; IDR 15,000,000,000; and Rp. $20,000,000,000$. In one exposure unit there are 10 groups that are used to separate the debtor's debit tray based on the range

The data collected is the SME credit exposure data of PT Bank XYZ (Persero) Tbk for the period of January 1, 2016 until December 31, 2018. Data is divided per month in each year so there are 36 periods of data. Credit exposure data consists of a performing loan and a nonperforming loan (NPL) with a range of exposures in accordance with the research limits of between Rp. 200 million to Rp. 25 billion.

After the appeal is carried out according to table 3, then the debtor grouping is done which defaults to each band, or it can be called Exposure at Default (EAD). Default exposure is the exposure of the portfolio of the SME of PT Bank XYZ (Persero) Tbk which has arrears of more than 90 days from the maturity date of the credit or declared default at the end of each month / period

This study uses data on average recovery rates on PT Bank XYZ (Persero) Tbk SME credit during the observation period, namely during the period $2016-2018$. After calculating 
the recovery rate each year, the recovery rate calculation is produced in 2016, 2017, and 2018 is $21.33 \%, 11.45 \%$ and $19.83 \%$ so the average recovery rates are $17.54 \%$ annually.

Loss Given Default (LGD) or sevirity loss or also known as real loss in the Credit Risk + method is obtained by subtracting the exposure value at default with the value of the recovery rates. This calculation will produce a real loss value that is used as a measure of the actual loss for each default. Loss Given Default which is also a real loss value per period obtained by summing the loss given default of each band in the same period.

The probability of default is calculated using the Poisson distribution method. Calculations are performed on each band group in each period. The number of default value is obtained when the number of default events has the highest probability of default or in other words the highest probability of default value occurs at a value of $n$, this value of $n$ is the number of default for each band group.

The unexpected number of default value occurs when cumulative probability of default reaches a value at the specified confidence level, which is $>95 \%$. Cumulative probability of default value is obtained by summing each probability value at $\mathrm{n}=0,1,2,3,4 \ldots \ldots \ldots \mathrm{n}$, so that the cumulative value reaches $>95 \%$.

The expected loss calculation is obtained by multiplying the expected number of default with the recovery rate and common exposure values. Expected number of default occurs when the number of default events has the highest probability of default. The highest probability of default is reached when the number of default events is the same as the expected number of default events. Expected loss is the amount of loss that can be estimated through historical calculation of the average loss due to credit risk that generally occurs. The expected loss must be covered by the provision of adequate pricing and the establishment of reserves for the provision of earning assets (PPAP).

Table 1. Expected Loss

\begin{tabular}{cccc}
\hline \multirow{2}{*}{ Month } & \multicolumn{3}{c}{ Year } \\
\cline { 2 - 4 } & 2016 & 2017 & 2018 \\
\hline Jan & $2,688,608,946,593.60$ & $2,001,531,580,227.52$ & $1,601,835,497,504.25$ \\
Feb & $2,214,785,420,606.32$ & $1,736,325,962,801.78$ & $1,614,553,673,763.26$ \\
Mar & $2,126,931,656,294.41$ & $1,648,439,836,403.96$ & $1,504,997,098,685.53$ \\
Apr & $2,419,791,863,409.00$ & $1,594,938,280,705.10$ & $1,495,764,537,435.11$ \\
Mei & $2,539,893,451,612.01$ & $1,539,747,739,525.31$ & $1,506,008,466,932.69$ \\
Jun & $2,396,874,244,549.42$ & $1,512,182,299,390.36$ & $1,490,611,849,469.13$ \\
Jul & $2,696,990,972,552.38$ & $1,538,977,601,861.24$ & $1,141,076,095,392.87$ \\
Ags & $2,736,672,823,036.60$ & $1,688,766,133,297.04$ & $1,183,245,820,138.66$ \\
Sep & $2,559,016,034,330.55$ & $1,698,336,036,371.72$ & $1,118,339,810,782.40$ \\
Oct & $2,629,063,217,047.71$ & $1,762,497,526,375.03$ & $1,114,372,555,272.92$ \\
Nov & $2,387,429,815,244.40$ & $1,772,871,199,347.77$ & $1,117,186,806,741.11$ \\
Des & $2,003,003,213,044.32$ & $1,697,395,098,445.29$ & $1,068,919,252,958.22$ \\
\hline
\end{tabular}

The calculation of unexpected loss is obtained by multiplying the number of default events when the cumulative probability default reaches a value of $\geq 95 \%$ with the value of recovery rate and common exposure. The value of unexpected loss in one period is the sum of the unexpected loss values of each band in that period. Unexpected loss is the Value at Risk (VaR) value of SME Credit. 
Table 2. Unexpected Loss

\begin{tabular}{cccc}
\hline \multirow{2}{*}{ Month } & \multicolumn{3}{c}{ Year } \\
\cline { 2 - 4 } & $3,737,581,960,000$ & $2,828,048,160,000$ & $\mathbf{2 0 1 8}$ \\
\hline Jan & $2,809,082,360,000$ & $2,486,828,680,000$ & $2,603,592,040,000$ \\
Feb & $2,680,114,920,000$ & $2,359,510,440,000$ & $2,622,887,680,000$ \\
Mar & $3,038,815,920,000$ & $2,298,160,200,000$ & $2,503,980,360,000$ \\
Apr & $3,301,368,560,000$ & $2,257,095,120,000$ & $2,659,499,920,000$ \\
Mei & $3,124,244,480,000$ & $2,100,421,120,000$ & $2,499,857,360,000$ \\
Jun & $3,565,900,240,000$ & $2,214,545,760,000$ & $1,825,169,640,000$ \\
Jul & $3,665,841,760,000$ & $2,455,823,720,000$ & $1,998,005,800,000$ \\
Ags & $3,472,225,680,000$ & $2,471,326,200,000$ & $2,012,518,760,000$ \\
Sep & $3,521,701,680,000$ & $2,706,502,120,000$ & $1,995,532,000,000$ \\
Oct & $3,278,939,440,000$ & $2,703,368,640,000$ & $1,945,396,320,000$ \\
Nov & $2,812,380,760,000$ & $2,705,347,680,000$ & $1,868,213,760,000$ \\
Des & &
\end{tabular}

Economic Capital is the amount of bank capital value that must be provided to anticipate maximum losses caused by defaults on the loan portfolio and result in unexpected loss. Economic capital can be obtained by calculating by reducing the value of unexpected loss with expected loss.

Table 3. Economic capital

\begin{tabular}{lccc}
\hline \multirow{2}{*}{ Month } & \multicolumn{3}{c}{ Year } \\
\cline { 2 - 4 } & 2016 & 2017 & 2018 \\
\hline Januari & $1,048,973,013,406$ & $826,516,579,772$ & $1,001,756,542,496$ \\
Februari & $594,296,939,394$ & $750,502,717,198$ & $1,008,334,006,237$ \\
Maret & $553,183,263,706$ & $71,070,603,596$ & $1,022,401,901,314$ \\
April & $619,024,056,591$ & $703,221,919,295$ & $1,008,215,822,565$ \\
Mei & $761,475,108,388$ & $717,347,380,475$ & $1,153,491,453,067$ \\
Juni & $727,370,235,451$ & $588,238,820,610$ & $1,009,245,510,531$ \\
Juli & $868,909,267,448$ & $675,568,158,139$ & $684,093,544,607$ \\
Agustus & $929,168,936,963$ & $767,057,586,703$ & $814,759,979,861$ \\
September & $913,209,645,669$ & $772,990,163,628$ & $894,178,949,218$ \\
Oktober & $892,638,462,952$ & $944,004,593,625$ & $881,159,444,727$ \\
November & $891,509,624,756$ & $930,497,440,652$ & $828,209,513,259$ \\
Desember & $809,377,546,956$ & $1,007,952,581,555$ & $799,294,507,042$ \\
\hline
\end{tabular}

\section{Conclusionn \& Recommendation}

Calculation of credit risk by using the CreditRisk + method on Bank XYZ's SME credit portfolio, the expected loss and unexpected loss at the end of 2016, 2017 and 2018 from year to year is increasingly downhill. This is in line with Bank XYZ's efforts to reduce the NPL of the SME segment which continues to be a priority and has produced positive results with achievements in 2018. Using the CreditRisk + method, you can calculate economic capital to deal with unexpected loses on credit in the period 2016 to 2018. Thus this method can calculate the capital reserves that must be formed by XYZ Bank in the future to minimize the risks that may be faced. This is caused by this method, credit risk takes into account the estimated losses that will be faced. 


\section{Referensi}

[1] S. Brannan, D. Mengle, C. Smithson, and M. Zmiewski, "Survey of credit portfolio management practices," 2002.

[2] Credit Suisse Financial Products, CreditRisk+: A Credit Risk Management Framework. 1997.

[3] B. for I. Settlements, Basel Commitee on Banking Supervision. Switzerland, 2006.

[4] A. Saunders and L. A, Credit Risk Measurement: New Approaches to CreditRisk Measurement. New Approach to Value at Risk and Other Paradigms (2nd ed). New York: John Wiley \& Sons, Inc., 2002. 